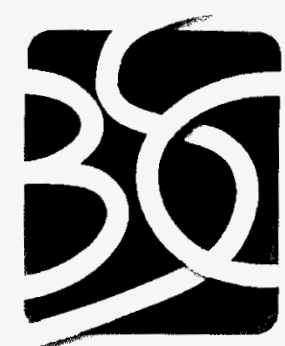

BECHTEL

SAIC Cowpaw IIC

\title{
EMPLACEMENT GANTRY ITS STANDARDS IDENTIFICATION STUDY
}

Prepared for:

U.S. Department of Energy

Office of Civilian Radioactive Waste Management

Office of Repository Development

1551 Hillshire Drive

Las Vegas, Nevada 89134-6321

Prepared by:

Bechtel SAIC Company, LLC

1180 Town Center Drive

Las Vegas, Nevada 89144

Under Contract Number

DE-AC28-01RW12101 


\section{DISCLAIMER}

This report was prepared as an account of work sponsored by an agency of the United States Government. Neither the United States Government nor any agency thereof, nor any of their employees, nor any of their contractors, subcontractors or their employees, makes any warranty, express or implied, or assumes any legal liability or responsibility for the accuracy, completeness, or any third party's use or the results of such use of any information, apparatus, product, or process disclosed, or represents that its use would not infringe privately owned rights. Reference herein to any specific commercial product, process, or service by trade name, trademark, manufacturer, or otherwise, does not necessarily constitute or imply its endorsement, recommendation, or favoring by the United States Government or any agency thereof or its contractors or subcontractors. The views and opinions of authors expressed herein do not necessarily state or reflect those of the United States Government or any agency thereof. 


\section{BSC ENGINEERING STUDY}

800-30R-HE00-00200-000-00A

Revision 00A

April 2005

\section{EMPLACEMENT GANTRY ITS STANDARDS IDENTIFICATION STUDY}

Prepared by:

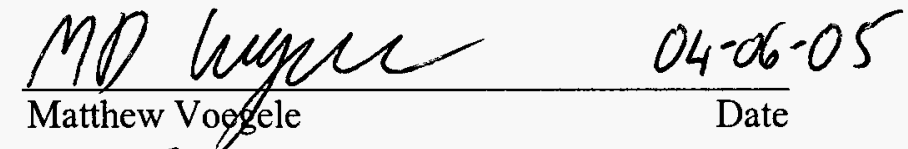

Reviewed By:

Approved by Project Engineer or Responsible Manager

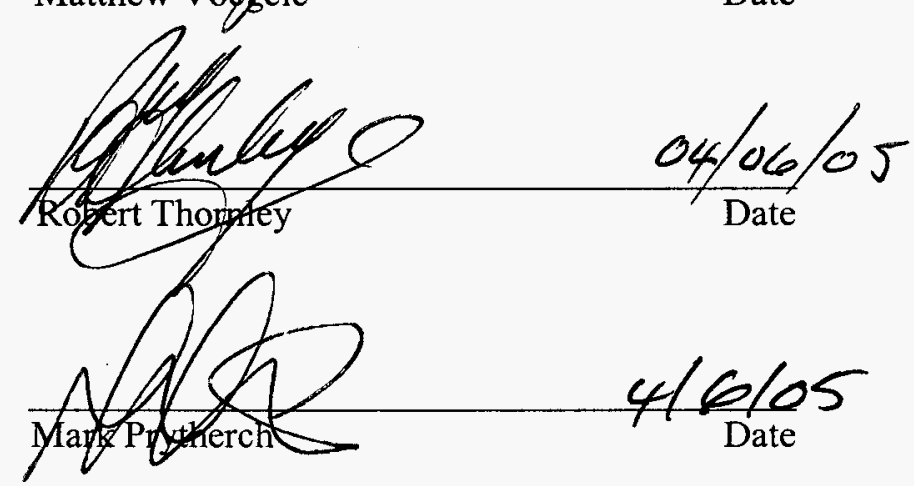




\section{CHANGE HISTORY}

\begin{tabular}{ccll}
$\begin{array}{c}\text { Revision } \\
\text { Number }\end{array}$ & $\begin{array}{l}\text { Interim } \\
\text { Change } \\
\text { No. }\end{array}$ & $\begin{array}{l}\text { Effective } \\
\text { Date }\end{array}$ & $\begin{array}{l}\text { Description Of Change } \\
0\end{array}$ \\
\cline { 1 - 2 } & 0 & $04 / 06 / 2005$ & Initial Issue
\end{tabular}




\section{CONTENTS}

Page

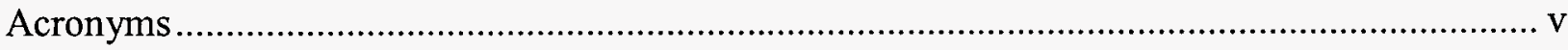

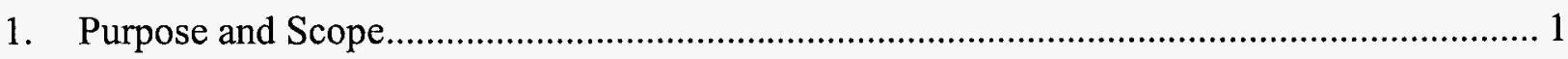

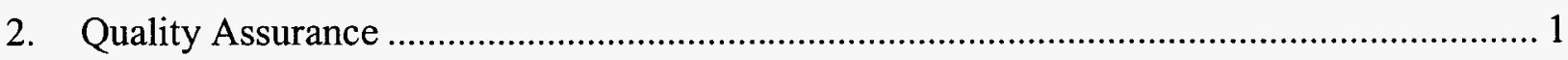

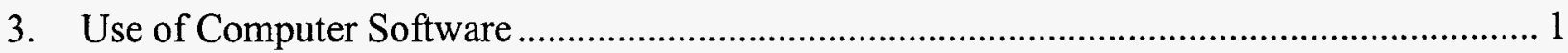

4. Emplacement Gantry Functional Description .................................................... 1

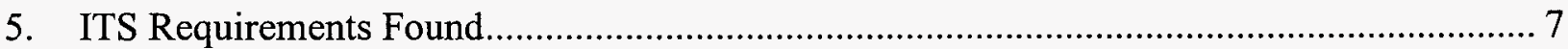

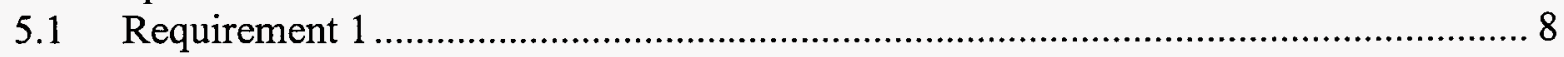

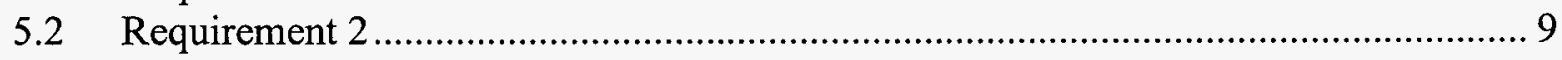

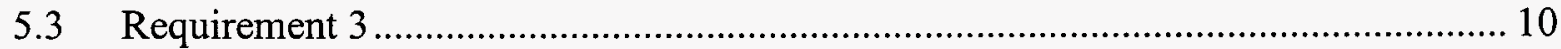

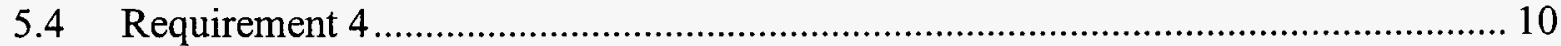

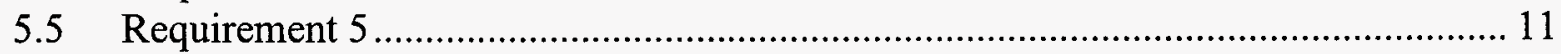

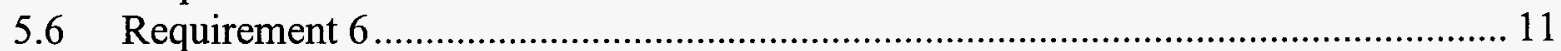

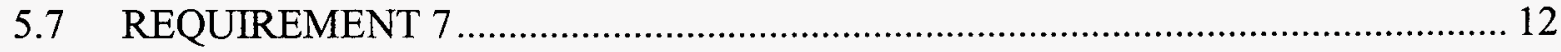

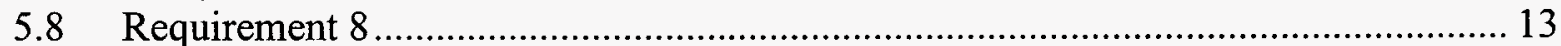

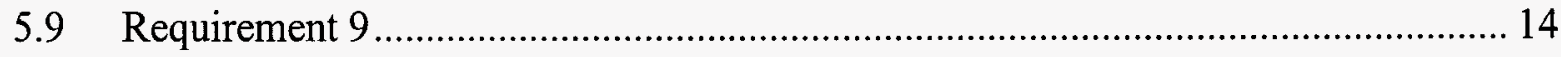

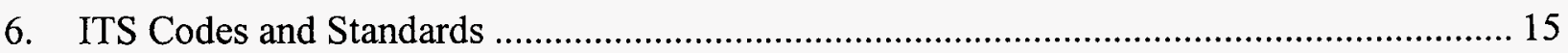

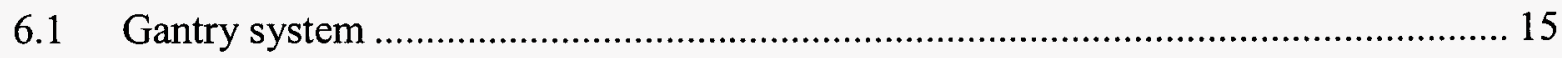

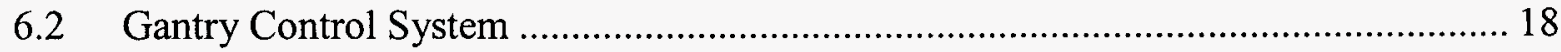

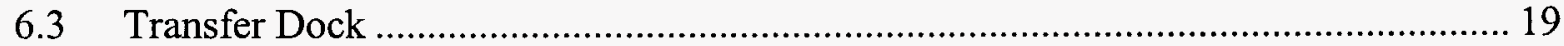

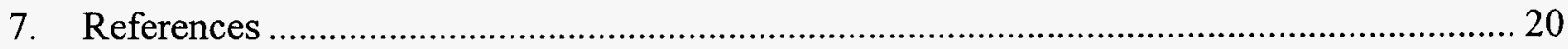

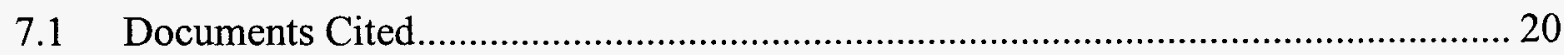

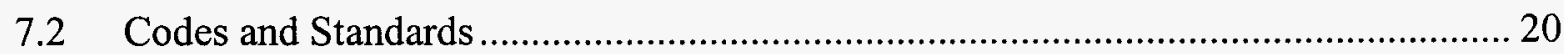

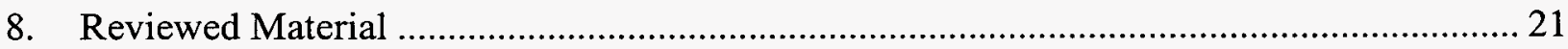

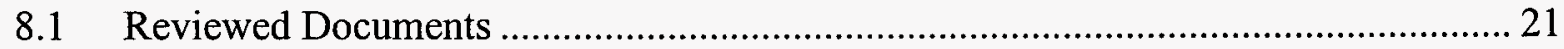

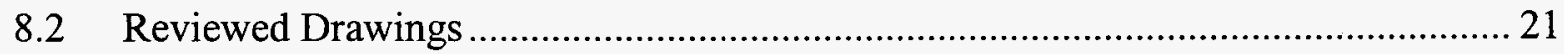

8.3 Reviewed Calculations/Analysis ................................................................... 21

8.4 Reviewed System Description Documents .................................................. 22

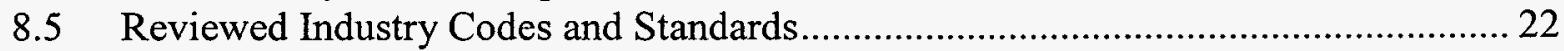

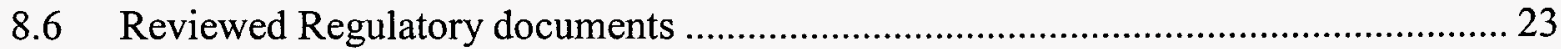

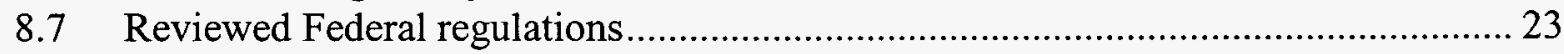

8.8 Reviewed DOE documents ....................................................................... 23 


\section{FIGURES}

Page

Figure 4-1, Overall System Block Flow Diagram ............................................................. 3

Figure 4-2, Gantry Drive Control System Block Flow Diagram ............................................ 4

Figure 4-3, Gantry Lift Control System Block Flow Diagram ................................................ 5

\section{TABLES}

Page

Table 5-1 Drop Rate SSCs for Requirement 1......................................................... 8

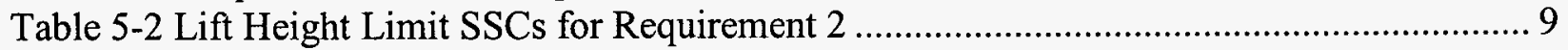

Table 5-3 Linear Motion SSCs for Requirement 3 ........................................................ 10

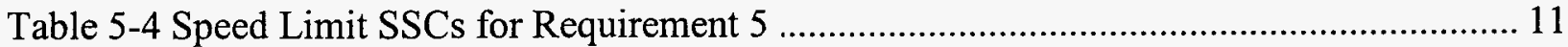

Table 5-5 Loss of Power SSC for Requirement 6.......................................................... 11

Table 5-6 Lift Height Probability SSCs for Requirement 7 ............................................. 12

Table 5-7 Load Drop Due to Fire SSCs for Requirement 8 .................................................. 13

Table 5-8 Tip Over and Breach of WP Caused By a Fire SSCs for Requirement 9 .................. 14

Table 6-1 Gantry Structure Frame Codes and Standards.................................................... 15

Table 6-2 Gantry Lifting Hooks Codes and Standards ....................................................... 15

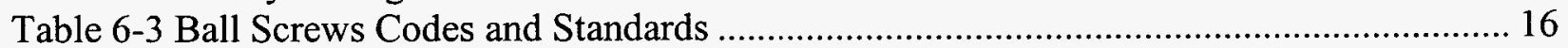

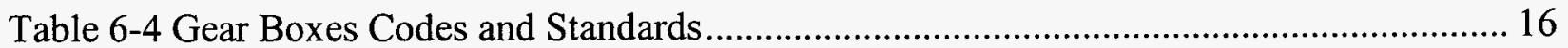

Table 6-5 Motors Codes and Standards .......................................................................... 16

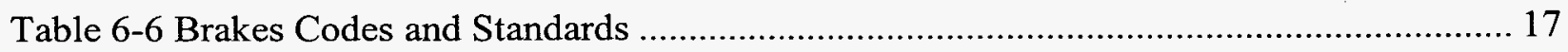

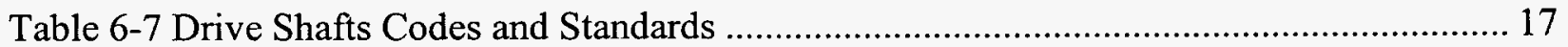

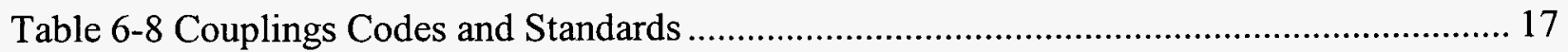

Table 6-9 Gantry Structure - Frame Codes and Standards .................................................. 18

Table 6-10 Gantry Structure - Bumpers Codes and Standards ............................................. 18

Table 6-11 Fire Protection System Codes and Standards .................................................... 18

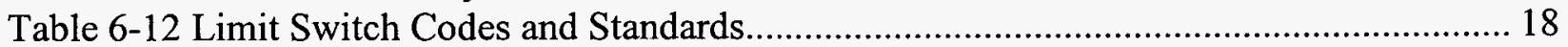

Table 6-13 Gantry Lifting Speed Control System Codes and Standards.................................. 19

Table 6-14 Lifting Control System Codes and Standards ..................................................... 19

Table 6-15 Gantry Speed Control System Codes and Standards.............................................. 19

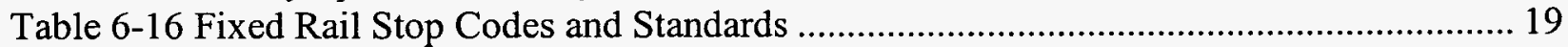

Table 6-17 Wheel Block Codes and Standards.................................................................... 19 


\section{ACRONYMS}

ASME The American Society of Mechanical Engineers

BSC Bechtel SAIC Company, LLC

CMAA Crane Manufacturer's Association of America

DOE U.S. Department of Energy

ITS important to safety

LA License Application

NFPA National Fire Protection Agency

NSDB Nuclear Safety Design Basis for License Application

SSC structure, system, and components

WP waste package 


\section{INTENTIONALLY LEFT BLANK}




\section{PURPOSE AND SCOPE}

To date, the project has established ITS performance requirements for SSCs based on identification and categorization of event sequences that may result in a radiological release. These performance requirements are defined within the NSDB. Further, SSCs credited with performing safe functions are classified as ITS. In turn, perform confirmation for these SSCs is sought through the use of consensus code and standards.

The purpose of this study is to identify applicable codes and standards for the WP Emplacement Gantry ITS SSCs. Further, this study will form the basis for selection and the extent of applicability of each code and standard.

This study is based on the design development completed for LA only. Accordingly, identification of ITS SSCs beyond those defined within the NSDB are based on designs that may be subject to further development during detail design. Furthermore, several design alternatives may still be under consideration to satisfy certain safety functions, and that final selection will not be determined until further design development has occurred. Therefore, for completeness, throughout this study alternative designs currently under considered will be discussed. Further, the results of this study will be subject to evaluation as part of a follow-on GAP analysis study.

Based on the results of this study the GAP analysis will evaluate each code and standard to ensure each ITS performance requirement is fully satisfied. When a performance requirement is not fully satisfied a "gap" is highlighted. Thereafter, the study will identify supplemental requirements to augment the code or standard to meet performance requirements. Further, the GAP analysis will identify non-standard areas of the design that will be subject to a Development Plan. Non-standard components and non-standard design configurations are defined as areas of the design that do not follow standard industry practices or codes and standards. Whereby, performance confirmation cannot be readily sought though use of consensus standards.

The ITS codes and standards identified in this document were developed by the Yucca Mountain Project personnel from the Emplacement \& Retrieval Project and are intended solely for the use of the Design and Engineering group in its work regarding the Emplacement and Retrieval system, specifically identification of Emplacement and Retrieval equipment codes and standards.

\section{QUALITY ASSURANCE}

This document was prepared in accordance with LP-ENG-014-BSC, Engineering Studies. The results or this document are only to be used as the basis for selection of applicable codes and standards and are not to be used directly to generate quality products. Therefore, this engineering study is not subject to requirements of the Quality Assurance Requirements and Description document (DOE 2004).

\section{USE OF COMPUTER SOFTWARE}

Computer software used, Microsoft Word 2000, in this study is classified as exempt from procedure LP-SI.11Q-BSC, Software Management. All software used to prepare this analysis is listed under Section 2.1 Software Not Subject To This Procedure, of LP-SI.11Q-BSC, Software Management.

\section{EMPLACEMENT GANTRY FUNCTIONAL DESCRIPTION}

The function of the waste package emplacement gantry, is to maneuver a waste package and its associated emplacement pallet, from the bedplate of the waste package transporter positioned at the emplacement drift dock, to the final emplacement position of the waste package within the emplacement drift. The 
same waste package emplacement gantry can be used for waste package and pallet retrieval, where the process, is a reversal of the emplacement procedure.

The gantry design is that the waste package emplacement gantry will be an electrically powered, selfpropelled, rail-based, remotely controlled gantry type crane. It will run on standard $135 \mathrm{lb} / \mathrm{yd}$ crane rails with a rail center distance of $10-\mathrm{ft}, 5$-in, and is capable of operating within the emplacement drifts bounding envelope and environment.

To perform its tasks the gantry has two basic functions. It must be able to lift or lower a waste package; and it must be able to carry the waste package linearly in or out of an emplacement drift. Figure 4-1, Overall System, is a block flow diagram showing the overall electrical and mechanical system. Figure 4-2, Gantry Drive Control, is a block flow diagram showing which components of the gantry are involved with driving the gantry linearly. Figure 4-3, Gantry Lift Control, is a block flow diagram showing which components of the gantry are involved with lifting and lowering a waste package.

The Control Logic Flow Diagrams as shown in Figure 4-1, Figure 4-2, and Figure 4-3 were prepared through dissection of the available drawings (see section 8.2 for a list of Drawings used) applicable to the existing design of the Gantry. To determine for each individual ITS requirement, which SSC within the concept as a whole could be accredited with the performance of that requirement. Together with the drawings, an evaluation of the Gantry design calculations (see section 8.3 for a list of Calculations/Analysis used), applicable to the existing design provided further pointers to the SSC accredited with ITS functions. Reference was also made to the Emplacement and Retrieval System Design Description Document, (see section 8.4 for a list of SDDs used). 


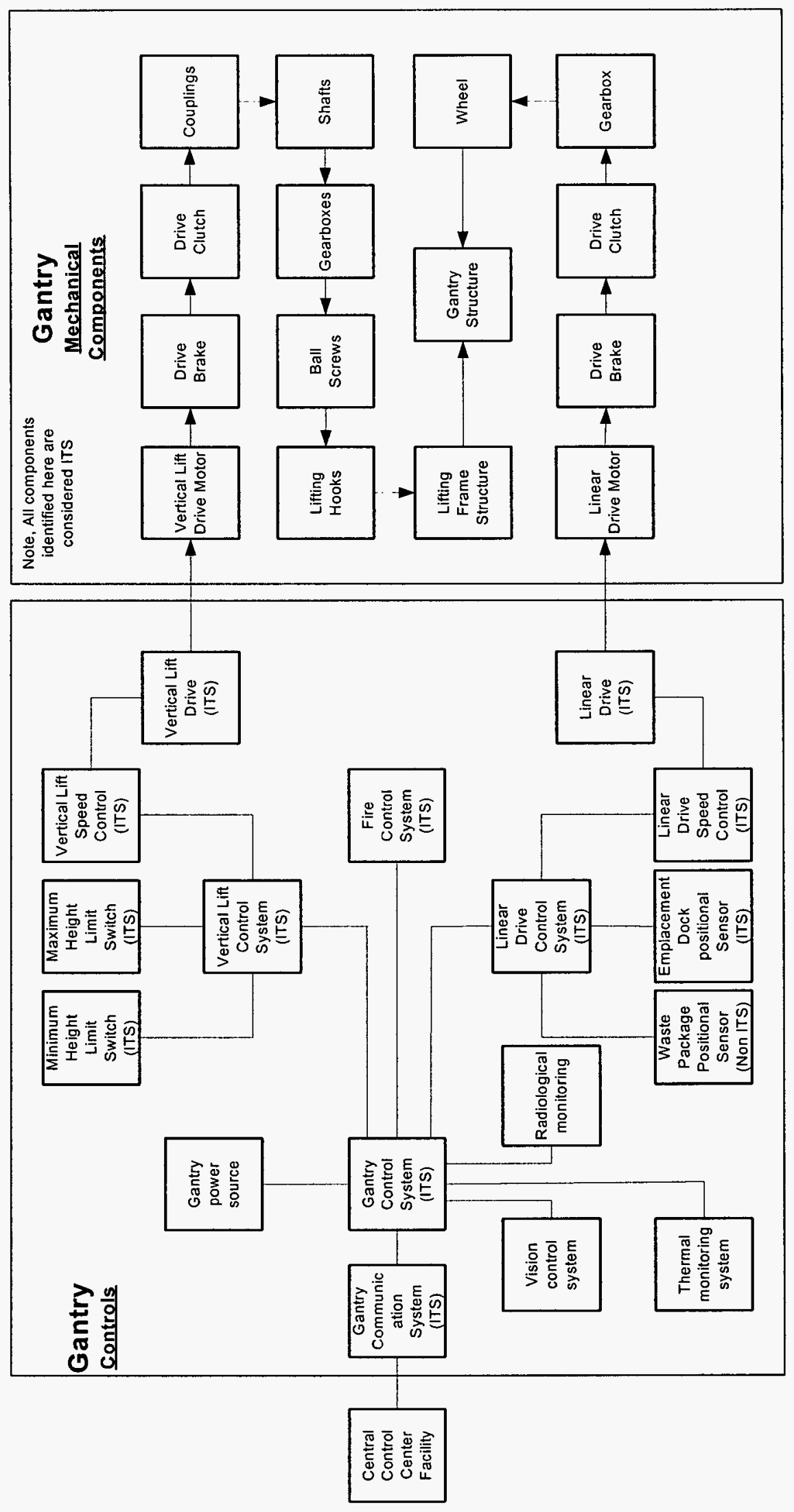

Figure 4-1, Overall System Block Flow Diagram 

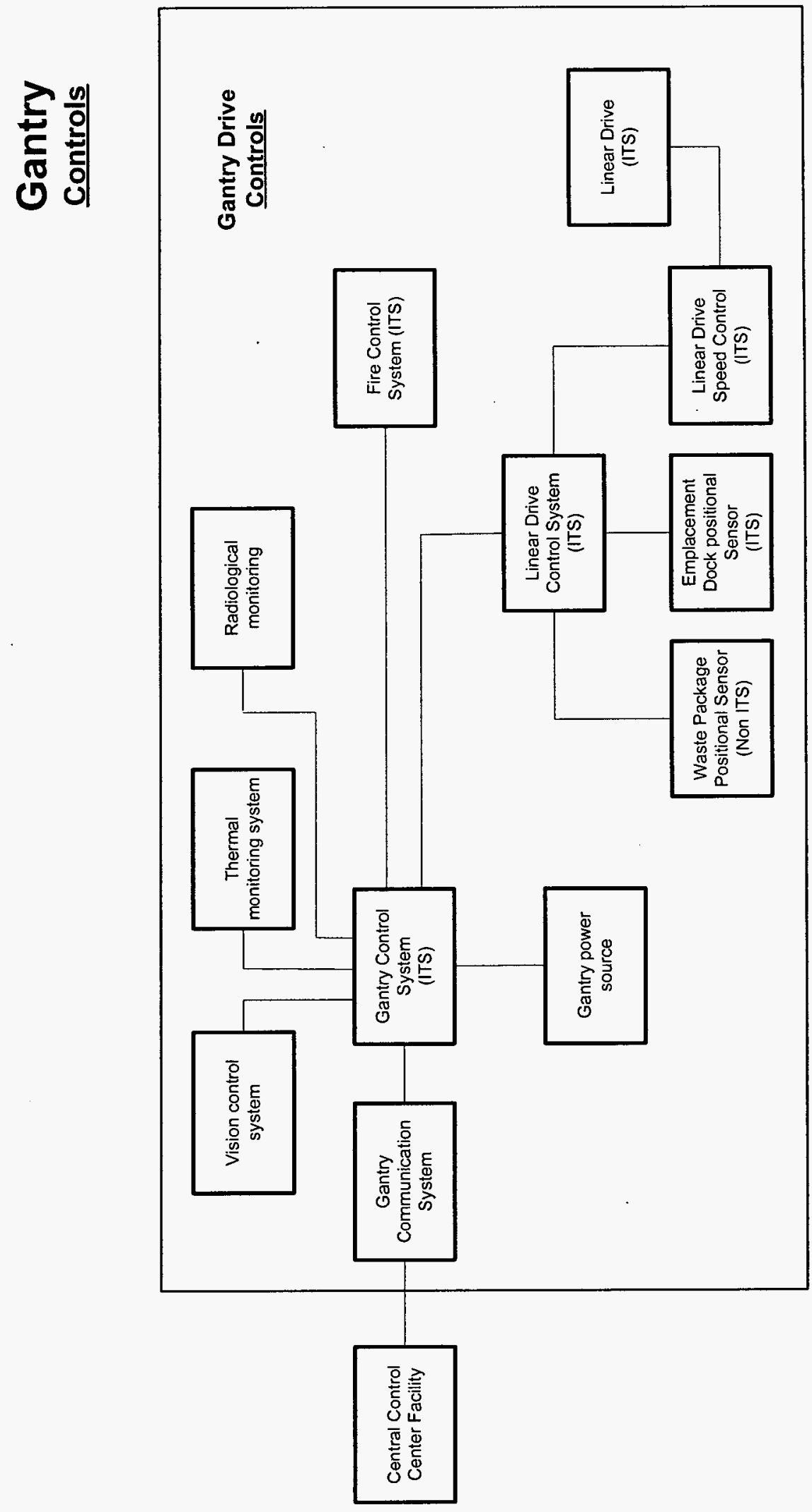

Figure 4-2, Gantry Drive Control System Block Flow Diagram 


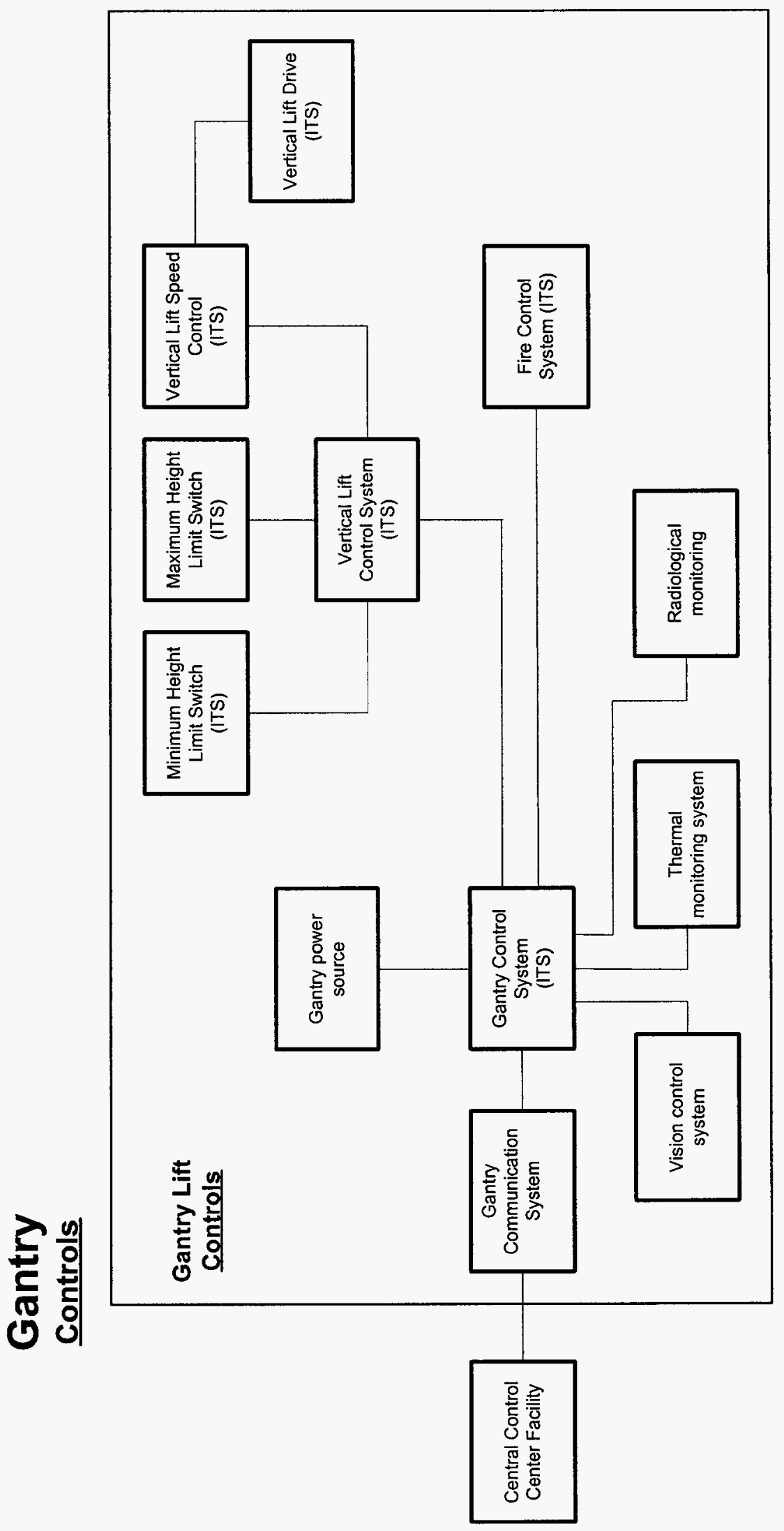

Figure 4-3, Gantry Lift Control System Block Flow Diagram 
INTENTIONALLY LEFT BLANK 


\section{ITS REQUIREMENTS FOUND}

The ITS requirements that were identified in this study were directly taken out of the Nuclear Safety Design Basis for License Application (BSC 2005). There were no additional documents identified that had any additional ITS requirements that had not already covered by the eleven requirements listed in the Nuclear Safety Design Basis for License Application. See Section 8 for a listing of the documents reviewed.

Each requirement that was identified in the Nuclear Safety Design Basis has been assigned its own requirement number, and is highlighted in an italic font, in this document. 


\subsection{REQUIREMENT 1}

The emplacement gantry shall have a drop rate of less than or equal to $1 \times 10^{-5}$ drops/transfer.

To prevent the emplacement gantry from dropping the waste package and pallet, all structures, systems or components directly within the load path were considered as ITS. The design concept driven by this safety requirement was to utilize a gantry crane principle and to incorporate single failure proof principles within the load path. This was achieved through the use of redundant features, for example the use of four lifting hooks driven by four ball screws, with a dual drive control system. In the gantry design these SSCs would start at the contact of the waste package pallet, achieved by the lifting hook fabrications and travel through the associated drive system, into the gantry structure and into the gantry support or wheels. To satisfy the drop rate requirement the gantry lifting system was dissected in the following manner. The gantry structure frame supports the lifting hooks. In order to drive the lifting hooks ball screws are needed. To control the movement of the ball screws: gearboxes, motors, brakes, drive shafts, limit switches, and a speed controller will be needed. Because each SSC identified in the lifting system could potentially cause a load drop they are considered ITS.

\begin{tabular}{|c|c|c|}
\hline SSC & ITS Function & $\begin{array}{l}\text { Code and } \\
\text { Standard } \\
\text { Reference }\end{array}$ \\
\hline Gantry Structure Frame & $\begin{array}{l}\text { - To support the Waste Package and Pallet. } \\
\text { To provide support to the Waste Package lifting features } \\
\text { and the drive system. } \\
\text { To provide support to the Gantry linear travel wheels, } \\
\text { and drive system. } \\
\text { To provide support to all additional equipment, lights, } \\
\text { cameras, control systems. }\end{array}$ & 6.1 .1 \\
\hline Gantry Lifting Hooks & $\begin{array}{l}\text { To interface with the WP pallet and to raise and lower the WP } \\
\text { and pallet. }\end{array}$ & 6.1 .2 \\
\hline Ball Screws & $\begin{array}{l}\text { To raise and lower the Lifting Hooks, therefore to support the } \\
\text { load of a waste package and pallet }\end{array}$ & 6.1 .3 \\
\hline Gear boxes & $\begin{array}{l}\text { To transfer the required rotational motion and energy from } \\
\text { the motor to the Ball Screws }\end{array}$ & 6.1 .4 \\
\hline Motors & To provide the required speed and energy to the gearboxes & 6.1 .5 \\
\hline Brakes & $\begin{array}{l}\text { To ensure when required that no movement of the lift drive } \\
\text { system occurs }\end{array}$ & 6.1 .6 \\
\hline Drive Shafts & $\begin{array}{l}\text { To transmit power and speed from the gear boxes to the ball } \\
\text { screws }\end{array}$ & 6.1 .7 \\
\hline Couplings & To connect drive shafts to gear boxes and ball screws & 6.1 .8 \\
\hline Limit Switches, Height & $\begin{array}{l}\text { To provide a signal to the control system that a position or } \\
\text { state of an SSC has been achieved. }\end{array}$ & 6.2 .1 \\
\hline Speed, Controller. & $\begin{array}{l}\text { To control the speed and power output from a power source } \\
\text { to a drive motor }\end{array}$ & 6.2 .2 \\
\hline
\end{tabular}

Table 5-1 Drop Rate SSCs for Requirement 1 


\subsection{REQUIREMENT 2}

The lift height limit for WPs in a horizontal orientation on the emplacement pallet is $6.5 \mathrm{ft}$ from the bottom of the pallet above an essentially unyielding surface.

To prevent the emplacement gantry from lifting the waste package and pallet above the lift height limit, all components directly in the lifting system were considered ITS. These would typically include, lifting hook fabrication, ball screws, motors, gearboxes, brakes, shafts, couplings, height lift limit switches, and the lift drive control system. This would also include the gantry lifting structure and the gantry structure itself as these would possibly contain physical movement stops for the lifting hooks.

\begin{tabular}{|c|c|c|}
\hline SSC & ITS Function & $\begin{array}{l}\text { Code and } \\
\text { Standard } \\
\text { Reference }\end{array}$ \\
\hline Gantry Structure Frame & $\begin{array}{l}\text { To support the Waste Package and Pallet. } \\
\text { - To provide support to the Waste Package lifting features } \\
\text { and the drive system. } \\
\text { To provide support to the Gantry linear travel wheels, } \\
\text { and drive system. } \\
\text { To provide support to all additional equipment, lights, } \\
\text { cameras, control systems. }\end{array}$ & 6.1 .1 \\
\hline Gantry Lifting Hooks & $\begin{array}{l}\text { To interface with the WP pallet and to raise and lower the WP } \\
\text { and pallet. }\end{array}$ & 6.1 .2 \\
\hline Ball Screws & $\begin{array}{l}\text { To raise and lower the Lifting Hooks, therefore to support the } \\
\text { load of a waste package and pallet }\end{array}$ & 6.1 .3 \\
\hline Gear boxes & $\begin{array}{l}\text { To transfer the required rotational motion and energy from } \\
\text { the motor to the Ball Screws }\end{array}$ & 6.1 .4 \\
\hline Motors & To provide the required speed and energy to the gearboxes & 6.1 .5 \\
\hline Brakes & $\begin{array}{l}\text { To ensure when required that no movement of the lift drive } \\
\text { system occurs }\end{array}$ & 6.1 .6 \\
\hline Drive Shafts & $\begin{array}{l}\text { To transmit power and speed from the gear boxes to the ball } \\
\text { screws }\end{array}$ & 6.1 .7 \\
\hline Couplings & To connect drive shafts to gear boxes and ball screws & 6.1 .8 \\
\hline Limit Switches, Height & $\begin{array}{l}\text { To provide a signal to the control system that a position or } \\
\text { state of an SSC has been achieved. }\end{array}$ & 6.2 .1 \\
\hline Speed, Controller. & $\begin{array}{l}\text { To control the speed and power output from a power source } \\
\text { to a drive motor }\end{array}$ & 6.2 .2 \\
\hline
\end{tabular}

Table 5-2 Lift Height Limit SSCs for Requirement 2 


\subsection{REQUIREMENT 3}

The WP emplacement gantry, carrying a WP, shall not be capable of running off the end of the emplacement drift or transfer dock rails.

To prevent the emplacement gantry from running off the end of the emplacement drift transfer dock, all structures, systems or components associated with controlling linear motion were considered as ITS. The gantry design driven by this safety requirement was to incorporate single failure proof principles within the travel path. This was achieved through the use of redundant features, for example there will be two rail stops at the end of the transfer dock, and there will be at least two limit switches to identify where the gantry is. In the gantry design, these SSCs would start with the basic need of stopping the gantry before it could fall off of the end of the emplacement drift. To prevent a fall the gantry would be controlled by an ITS speed control. To back up the speed control limit switches would be installed to help the gantry realize where it is. In the event that the speed control and the limit switches failed a rail stop and bumper system would be used.

\begin{tabular}{|l|l|c|}
\hline \multicolumn{1}{|c|}{ SSC } & \multicolumn{1}{|c|}{ ITS Function } & $\begin{array}{c}\text { Code and } \\
\text { Standard } \\
\text { Reference }\end{array}$ \\
\hline Limit Switches & $\begin{array}{l}\text { To provide a signal to the control system that a position or } \\
\text { state of an SSC has been achieved. }\end{array}$ & 6.2 .1 \\
\hline $\begin{array}{l}\text { Gantry Drive Speed } \\
\text { controller }\end{array}$ & $\begin{array}{l}\text { To control the speed and power output from a power source to } \\
\text { a drive motor }\end{array}$ & 6.2 .4 \\
\hline Bumpers & $\begin{array}{l}\text { To provide a means of absorbing movement energy in a fault } \\
\text { or collision condition }\end{array}$ & 6.1 .10 \\
\hline Fixed rail stops & To prevent movement of the gantry off the rail ends & 6.3 .1 \\
\hline
\end{tabular}

Table 5-3 Linear Motion SSCs for Requirement 3

\subsection{REQUIREMENT 4}

If the WP emplacement gantry were to fall on the WP transporter and impact the WP, it shall not cause the WP to be breached.

There are no identified applicable codes or standards that can be used to satisfy this requirement. 


\subsection{REQUIREMENT 5}

The WP emplacement gantry shall be limited to a maximum speed of $15 \mathrm{mph}$ such that a collision at this speed limit shall not result in a WP breach.

To prevent the emplacement gantry from exceeding a maximum speed, all structures, systems or components directly associated with speed control are considered ITS. The gantry design driven by this safety requirement was to incorporate single failure proof principles within the linear drive system. This was achieved through the use of redundant features for example there will be a total of four drive motor assemblies. In the gantry design these SSCs would start at the contact of the wheels, travel through the associated drive system, into the gantry speed controller. To satisfy the maximum speed requirement the gantry drive system was dissected in the following manner. The wheel blocks, drive motors, gearboxes, drive brakes and speed controller are all involved in controlling the gantry speed.

\begin{tabular}{|l|l|c|}
\hline \multicolumn{1}{|c|}{ SSC } & \multicolumn{1}{|c|}{ ITS Function } & $\begin{array}{c}\text { Code and } \\
\text { Standard } \\
\text { Reference }\end{array}$ \\
\hline Wheel blocks, Wheels & To provide guidance, motion and support for the gantry & 6.3 .2 \\
\hline Drive Motors & To provide the required speed and energy to the gearboxes & 6.1 .5 \\
\hline Drive Gearboxes & To provide the required rotational speed to the Wheels & 6.1 .4 \\
\hline Drive Brakes & $\begin{array}{l}\text { To ensure when required that no movement of the linear drive } \\
\text { system occurs }\end{array}$ & 6.1 .6 \\
\hline $\begin{array}{l}\text { Gantry Drive Speed } \\
\text { Controller }\end{array}$ & $\begin{array}{l}\text { To control the speed and power output from a power source to } \\
\text { a drive motor }\end{array}$ & 6.2 .4 \\
\hline
\end{tabular}

Table 5-4 Speed Limit SSCs for Requirement 5

\subsection{REQUIREMENT 6}

Upon a loss of power, the WP emplacement gantry shall be designed to stop, retain the load, and enter a locked mode; upon a restoration of power, the WP emplacement gantry shall stay in the locked mode until operator action is taken.

To prevent the emplacement gantry from moving upon loss of power, all components directly associated within the control system were considered as ITS. The gantry design driven by this safety requirement was to incorporate single failure proof principles within the control system. This was achieved through the use of redundant features, for example the control system may have two controllers built in. In the gantry design the SSC affected is the control system, because this is the system that will stop the gantry when there is a loss of power.

\begin{tabular}{|l|l|c|}
\hline \multicolumn{1}{|c|}{ SSC } & \multicolumn{1}{|c|}{ ITS Function } & $\begin{array}{c}\text { Code and } \\
\text { Standard } \\
\text { Reference }\end{array}$ \\
\hline Control System & $\begin{array}{l}\text { To provide an interface from incoming power supplies and } \\
\text { communication systems to the controllers }\end{array}$ & 6.2 .3 \\
\hline
\end{tabular}

Table 5-5 Loss of Power SSC for Requirement 6 


\subsection{REQUIREMENT 7}

The conditional probability of the WP emplacement gantry having exceeded the lift height limit given that a drop occurred shall be $10^{-4}$ or less.

To prevent the emplacement gantry from exceeding the conditional probability of lifting the waste package and pallet above the lift height limit, all components directly in the lifting system were considered ITS. These would typically include, lifting hook fabrication, ball screws, motors, gearboxes, brakes, shafts, couplings, height lift limit switches, and the lift drive control system. This would also include the gantry lifting structure and the gantry structure itself as these would possibly contain physical movement stops for the lifting hooks.

\begin{tabular}{|c|c|c|}
\hline SSC & ITS Function & $\begin{array}{l}\text { Code and } \\
\text { Standard } \\
\text { Reference }\end{array}$ \\
\hline Gantry Structure Frame & $\begin{array}{l}\text { To support the Waste Package and Pallet. } \\
\text { To provide support to the Waste Package lifting features } \\
\text { and the drive system. } \\
\text { To provide support to the Gantry linear travel wheels, } \\
\text { and drive system. } \\
\text { To provide support to all additional equipment, lights, } \\
\text { cameras, control systems. }\end{array}$ & 6.1 .1 \\
\hline Gantry Lifting Hooks & $\begin{array}{l}\text { To interface with the WP pallet and to raise and lower the WP } \\
\text { and pallet. }\end{array}$ & 6.1 .2 \\
\hline Ball Screws & $\begin{array}{l}\text { To raise and lower the Lifting Hooks, therefore to support the } \\
\text { load of a waste package and pallet }\end{array}$ & 6.1 .3 \\
\hline Gear boxes & $\begin{array}{l}\text { To transfer the required rotational motion and energy from } \\
\text { the motor to the Ball Screws }\end{array}$ & 6.1 .4 \\
\hline Motors & To provide the required speed and energy to the gearboxes & 6.1 .5 \\
\hline Brakes & $\begin{array}{l}\text { To ensure when required that no movement of the lift drive } \\
\text { system occurs }\end{array}$ & 6.1 .6 \\
\hline Drive Shafts & $\begin{array}{l}\text { To transmit power and speed from the gear boxes to the ball } \\
\text { screws }\end{array}$ & 6.1 .7 \\
\hline Couplings & To connect drive shafts to gear boxes and ball screws & 6.1 .8 \\
\hline Limit Switches, Height & $\begin{array}{l}\text { To provide a signal to the control system that a position or } \\
\text { state of an SSC has been achieved. }\end{array}$ & 6.2 .1 \\
\hline Speed, Controller. & $\begin{array}{l}\text { To control the speed and power output from a power source } \\
\text { to a drive motor }\end{array}$ & 6.2 .2 \\
\hline
\end{tabular}

Table 5-6 Lift Height Probability SSCs for Requirement 7 


\subsection{REQUIREMENT 8}

In the event of a credible fire in an area where waste forms are present, the temperature of machinery that handles or transports $S N F / H L W$ shall not reach a level that would make it drop its load.

To prevent the emplacement gantry from dropping the waste package in the event of a fire, all structures, systems or components directly associated within the load path were considered as ITS. The gantry design driven by this safety requirement was to incorporate single failure proof principles within the load path. This was achieved through the use of redundant features, for example the control system may have two controllers built in. In addition, the control boxes containing the electronic control systems would include automatic fire detection and suppression systems within them. In the gantry design, the affected SSC are the control system and the fire protection system. In addition, the gantry structure frame was identified because it directly supports the waste package and will need to withstand a credible fire to hold up a waste package.

\begin{tabular}{|l|l|c|}
\hline \multicolumn{1}{|c|}{ SSC } & \multicolumn{1}{|c|}{ ITS Function } & $\begin{array}{c}\text { Code and } \\
\text { Standard } \\
\text { Reference }\end{array}$ \\
\hline Gantry Structure Frame & \begin{tabular}{l} 
- $\begin{array}{l}\text { To support the Waste Package and Pallet. } \\
\text { To provide support to the Waste Package lifting features } \\
\text { and the drive system. } \\
\text { To provide support to the Gantry linear travel wheels, } \\
\text { and drive system. } \\
\text { To provide support to all additional equipment, lights, } \\
\text { cameras, control systems. }\end{array}$ \\
\hline Control system
\end{tabular} & $\begin{array}{l}\text { To provide an interface from incoming power supplies and } \\
\text { communication systems to the controllers }\end{array}$ \\
\hline Fire protection system & $\begin{array}{l}\text { To provide an indicator that a fault scenario, fire has occurred } \\
\text { within an enclosure }\end{array}$ & 6.1 \\
\hline
\end{tabular}

Table 5-7 Load Drop Due to Fire SSCs for Requirement 8 


\subsection{REQUIREMENT 9}

A tip over and breach of a WP while on machinery that handles or transports $S N F / H L W$ due to uncontrolled movements produced by a loss of power or a spurious signal caused by a fire shall have a probability of less than $1 \times 10^{-5}$ over the life of the facility.

To prevent the emplacement gantry from dropping the waste package in the event of a fire, all structures, systems or components directly associated within the load path were considered as ITS. The gantry design driven by this safety requirement was to incorporate single failure proof principles within the load path. This was achieved through the use of redundant features, for example the control system may have two controllers. The control boxes housing the control systems would include automatic fire detection and suppression systems within them. Therefore the affected ITS SSCs are the control system and the fire protection system.

\begin{tabular}{|l|l|c|}
\hline \multicolumn{1}{|c|}{ SSC } & \multicolumn{1}{|c|}{ ITS Function } & $\begin{array}{c}\text { Code and } \\
\text { Standard } \\
\text { Reference }\end{array}$ \\
\hline Control system & $\begin{array}{l}\text { To provide an interface from incoming power supplies and } \\
\text { communication systems to the controllers }\end{array}$ & 6.2 .2 \\
\hline Fire protection system & $\begin{array}{l}\text { To provide an indicator that a fault scenario, fire has occurred } \\
\text { within an enclosure }\end{array}$ & 6.1 .11 \\
\hline
\end{tabular}

Table 5-8 Tip Over and Breach of WP Caused By a Fire SSCs for Requirement 9 


\section{ITS CODES AND STANDARDS}

In order to capture all of the codes and standards an exhaustive study was performed. This study consisted of an evaluation of industry consensus codes and standards to identify applicability to the ITS SSCs. Refer to section $8.5,8.6,8.7$ and 8.8 for a list of codes, standards, regulations, and directives reviewed for this section. The codes and standards selected were based upon their applicability to the requirements of the ITS SSCs, in particular within a nuclear environment. The evaluation of the identified industry codes and standards (see section 7.2 for a list of identified Industry Codes and Standards) looked at the applicable sections of each code and standard. This was done to ensure that the design, construction, installation, testing, and operations were all analyzed to show how each of the of the particular SSC will satisfy the ITS requirements.

ASME NOG 1 was selected as the primary code and standard because it covers electric overhead and gantry multiple girder cranes with top running bridge and trolley used at nuclear facilities and components of cranes at nuclear facilities. ASME NOG-1 was chosen over NUM-1 because most of the equipment attributes are comparable to an overhead gantry crane rather than an under-running monorail or single girder crane.

CMAA 70 was invoked by the selection of ASME NOG 1. CMAA 70 contains specifications and information that applies to top running bridge and gantry type multiple girder electric overhead traveling cranes.

Note: The extent of the applicability of each code and standard identified will be further defined through the completion of a subsequent gap analysis study.

\subsection{GANTRY SYSTEM}

\subsubsection{Gantry Structure Frame}

\begin{tabular}{|l|l|l|l|}
\hline $\begin{array}{c}\text { Code \& } \\
\text { Standard }\end{array}$ & Section & \multicolumn{1}{|c|}{ Title } & \multicolumn{1}{c|}{ Code \& Standard Section Contents } \\
\hline ASME NOG.1 & 4000 & $\begin{array}{l}\text { Requirements for structural } \\
\text { components }\end{array}$ & $\begin{array}{l}\text { Specifies the design criteria, design, materials and fabrication } \\
\text { procedures for structural components }\end{array}$ \\
\hline ASME NOG.1 & 4300 & Design Criteria - Stresses & Specifies Basic allowable stresses for structural steel members \\
\hline ASME NOG.1 & 4345 & Gantry Frame Deflection & $\begin{array}{l}\text { This details additional criteria applicable to gantry frame } \\
\text { deflections. }\end{array}$ \\
\hline ASME NOG.1 & 4450 & Gantry Frames & This section deals with fabrication, material and loadings \\
\hline ASME NOG.1 & 7000 & Inspection and Testing & Table 7200-1 states required testing for hooks \\
\hline
\end{tabular}

Table 6-1 Gantry Structure Frame Codes and Standards

\subsubsection{Gantry Lifting Hooks}

\begin{tabular}{|l|l|l|l|}
\hline $\begin{array}{c}\text { Code \& } \\
\text { Standard }\end{array}$ & Section & \multicolumn{1}{|c|}{ Title } & \multicolumn{1}{c|}{ Code \& Standard Section Contents } \\
\hline ASME NOG.1 & 4000 & $\begin{array}{l}\text { Requirements for structural } \\
\text { components }\end{array}$ & $\begin{array}{l}\text { Specifies the design criteria, design, materials and fabrication } \\
\text { procedures for structural components }\end{array}$ \\
\hline ASME NOG.1 & 4300 & Design Criteria - Stresses & Specifies Basic allowable stresses for structural steel members \\
\hline ASME NOG.1 & 7000 & Inspection and Testing & Table 7200-1 states required testing for hooks \\
\hline
\end{tabular}

Table 6-2 Gantry Lifting Hooks Codes and Standards 


\subsubsection{Ball Screws}

ASME B5.48 was chosen as the standard to be used for ball screws because it covers definitions, classes of ball screws, recommended combinations of screw diameters and leads, recommended drawing format, and performance characteristics of ball screw and nut assemblies as applied to machine tools.

ASME B1.5 was chosen as the standard for ACME Screw Threads because it provides specifications, formulas, and tables for screw threads. This Standard provides for two general applications of ACME threads: namely, general purpose and centralizing. The limits and tolerances in this Standard relate to single-start Acme threads and may be used, if considered suitable, for multiple-start Acme threads. The latter threads are used to provide relatively fast traversing motion when necessary.

\begin{tabular}{|l|l|l|l|}
\hline $\begin{array}{c}\text { Code \& } \\
\text { Standard }\end{array}$ & Section & \multicolumn{1}{|c|}{ Title } & \multicolumn{1}{c|}{ Code \& Standard Section Contents } \\
\hline ASME NOG.1 & 5000 & Mechanical & $\begin{array}{l}\text { General, material, design and performance criteria and } \\
\text { component design. }\end{array}$ \\
\hline ASME NOG.1 & 5150 -(a) & Critical Items & $\begin{array}{l}\text { Components located between the load and the source of energy } \\
\text { holding the load. }\end{array}$ \\
\hline ASME NOG.1 & 5416 & $\begin{array}{l}\text { Single failure Proof } \\
\text { Features }\end{array}$ & $\begin{array}{l}\text { Failure of a single hoist mechanism component will not result } \\
\text { in the loss of a load. This section discusses methods to achieve } \\
\text { this. }\end{array}$ \\
\hline ASME B5.48 & Entire & Ball Screws & \\
\hline ASME B1.5 & Entire & ACME Screw Threads & \\
\hline
\end{tabular}

Table 6-3 Ball Screws Codes and Standards

\subsubsection{Gear Boxes}

\begin{tabular}{|l|l|l|l|}
\hline $\begin{array}{c}\text { Code \& } \\
\text { Standard }\end{array}$ & \multicolumn{1}{|c|}{ Section } & \multicolumn{1}{|c|}{ Title } & \multicolumn{1}{c|}{ Code \& Standard Section Contents } \\
\hline ASME NOG.1 & 5000 & Mechanical & $\begin{array}{l}\text { General, material, design and performance criteria and } \\
\text { component design. }\end{array}$ \\
\hline ASME NOG.1 & $5150-(\mathrm{a})$ & Critical Items & $\begin{array}{l}\text { Components located between the load and the source of energy } \\
\text { holding the load. }\end{array}$ \\
\hline ASME NOG.1 & 5416 & $\begin{array}{l}\text { Single failure Proof } \\
\text { Features }\end{array}$ & $\begin{array}{l}\text { Failure of a single hoist mechanism component will not result in } \\
\text { the loss of a load. This section discusses methods to achieve this. }\end{array}$ \\
\hline
\end{tabular}

Table 6-4 Gear Boxes Codes and Standards

\subsubsection{Motors}

\begin{tabular}{|l|l|l|l|}
\hline $\begin{array}{c}\text { Code \& } \\
\text { Standard }\end{array}$ & Section & \multicolumn{1}{|c|}{ Title } & \multicolumn{1}{c|}{ Code \& Standard Section Contents } \\
\hline ASME NOG.1 & 5000 & Mechanical & $\begin{array}{l}\text { General, material, design and performance criteria and } \\
\text { component design. }\end{array}$ \\
\hline ASME NOG.1 & $5150-(\mathrm{a})$ & Critical Items & $\begin{array}{l}\text { Components located between the load and the source of energy } \\
\text { holding the load. }\end{array}$ \\
\hline ASME NOG.1 & 5416 & $\begin{array}{l}\text { Single failure Proof } \\
\text { Features }\end{array}$ & $\begin{array}{l}\text { Failure of a single hoist mechanism component will not result in } \\
\text { the loss of a load. This section discusses methods to achieve } \\
\text { this. }\end{array}$ \\
\hline ASME NOG.1 & 6000 & Entire & Electrical components \\
\hline ASME NOG.1 & 6470 & Motors & Details motor selection applicable to type 1 cranes \\
\hline CMAA 70 & $70-5.2$ & Motors AC and DC & Details design requirements applicable to motor selection \\
\hline
\end{tabular}

Table 6-5 Motors Codes and Standards 


\subsubsection{Brakes}

\begin{tabular}{|l|l|l|l|}
\hline $\begin{array}{c}\text { Code \& } \\
\text { Standard }\end{array}$ & Section & \multicolumn{1}{|c|}{ Title } & \multicolumn{1}{c|}{ Code \& Standard Section Contents } \\
\hline ASME NOG.1 & 5000 & Mechanical & $\begin{array}{l}\text { General, material, design and performance criteria and } \\
\text { component design. }\end{array}$ \\
\hline ASME NOG.1 & $5150-$ (a) & Critical Items & $\begin{array}{l}\text { Components located between the load and the source of energy } \\
\text { holding the load. }\end{array}$ \\
\hline ASME NOG.1 & 5416 & $\begin{array}{l}\text { Single failure Proof } \\
\text { Features }\end{array}$ & $\begin{array}{l}\text { Failure of a single hoist mechanism component will not result in } \\
\text { the loss of a load. This section discusses methods to achieve } \\
\text { this. }\end{array}$ \\
\hline ASME NOG.1 & 6000 & Entire & Electrical components \\
\hline ASME NOG.1 & 6422 & Hoist Brakes & Hoists that handle critical loads on type 1 cranes. \\
\hline CMAA 70 & $70-4.9$ & Brakes & Details design requirements applicable to brakes selection \\
\hline
\end{tabular}

Table 6-6 Brakes Codes and Standards

\subsubsection{Drive Shafts}

\begin{tabular}{|l|l|l|l|}
\hline $\begin{array}{c}\text { Code \& } \\
\text { Standard }\end{array}$ & Section & \multicolumn{1}{|c|}{ Title } & \multicolumn{1}{c|}{ Code \& Standard Section Contents } \\
\hline ASME NOG.1 & 5000 & Mechanical & $\begin{array}{l}\text { General, material, design and performance criteria and } \\
\text { component design. }\end{array}$ \\
\hline ASME NOG.1 & $5150-(\mathrm{a})$ & Critical Items & $\begin{array}{l}\text { Components located between the load and the source of energy } \\
\text { holding the load. }\end{array}$ \\
\hline ASME NOG.1 & 5416 & $\begin{array}{l}\text { Single failure Proof } \\
\text { Features }\end{array}$ & $\begin{array}{l}\text { Failure of a single hoist mechanism component will not result in } \\
\text { the loss of a load. This section discusses methods to achieve } \\
\text { this. }\end{array}$ \\
\hline CMAA 70 & $70-4.11$ & Shafting & Details design requirements applicable to shaft selection. \\
\hline
\end{tabular}

Table 6-7 Drive Shafts Codes and Standards

\subsubsection{Couplings}

\begin{tabular}{|l|l|l|l|}
\hline $\begin{array}{c}\text { Code \& } \\
\text { Standard }\end{array}$ & Section & \multicolumn{1}{|c|}{ Title } & \multicolumn{1}{c|}{ Code \& Standard Section Contents } \\
\hline ASME NOG.1 & 5000 & Mechanical & $\begin{array}{l}\text { General, material, design and performance criteria and } \\
\text { component design. }\end{array}$ \\
\hline ASME NOG.1 & $5150-($ a) & Critical Items & $\begin{array}{l}\text { Components located between the load and the source of energy } \\
\text { holding the load. }\end{array}$ \\
\hline ASME NOG.1 & 5416 & $\begin{array}{l}\text { Single failure Proof } \\
\text { Features }\end{array}$ & $\begin{array}{l}\text { Failure of a single hoist mechanism component will not result in } \\
\text { the loss of a load. This section discusses methods to achieve } \\
\text { this. }\end{array}$ \\
\hline CMAA 70 & $70-4.12$ & Couplings & Details design requirements applicable to drive shaft selection \\
\hline
\end{tabular}

Table 6-8 Couplings Codes and Standards 


\subsubsection{Gantry Structure - Frame}

\begin{tabular}{|l|l|l|l|}
\hline $\begin{array}{c}\text { Code \& } \\
\text { Standard }\end{array}$ & Section & \multicolumn{1}{|c|}{ Title } & \multicolumn{1}{c|}{ Code \& Standard Section Contents } \\
\hline ASME NOG.1 & 4000 & $\begin{array}{l}\text { Requirements for structural } \\
\text { components }\end{array}$ & $\begin{array}{l}\text { Specifies the design criteria, design, materials and fabrication } \\
\text { procedures for structural components }\end{array}$ \\
\hline ASME NOG.1 & 4300 & Design Criteria - Stresses & Specifies Basic allowable stresses for structural steel members \\
\hline ASME NOG.1 & 4345 & Gantry Frame Deflections & $\begin{array}{l}\text { In addition to section 4300 criteria, this section specifies Gantry } \\
\text { frame deflections }\end{array}$ \\
\hline ASME NOG.1 & 4450 & Gantry Frames & Deals with Gantry Frame component design \\
\hline
\end{tabular}

Table 6-9 Gantry Structure - Frame Codes and Standards

\subsubsection{Gantry Structure - Bumpers}

\begin{tabular}{|c|l|l|l|}
\hline $\begin{array}{c}\text { Code \& } \\
\text { Standard }\end{array}$ & Section & Title & Code \& Standard Section Contents \\
\hline ASME NOG.1 & 5458 & Bumpers and Stops & $\begin{array}{l}\text { Defines design criteria applicable to bumper design and energy } \\
\text { absorbing capacities. }\end{array}$ \\
\hline
\end{tabular}

Table 6-10 Gantry Structure - Bumpers Codes and Standards

\subsubsection{Fire Protection System}

NFPA 801.2003 addresses fire protection requirements intended to reduce the risk of fires and explosions at facilities handling radioactive materials. These requirements are applicable to all locations where radioactive materials are stored, handled, or used in quantities and conditions requiring government oversight and/or license (e.g., U.S. Nuclear Regulatory Commission or U.S. Department of Energy) to possess or use these materials and to all other locations with equal quantities or conditions. This standard shall not apply to commercial power reactors that are covered by NFPA 804, Standard for Fire Protection for Advanced Light Water Reactor Electric Generating Plants, and NFPA 805, Performance-Based Standard for Fire Protection for Light Water Reactor Electric Generating Plants.

\begin{tabular}{|l|l|l|l|}
\hline $\begin{array}{c}\text { Code \& } \\
\text { Standard }\end{array}$ & Section & Title & Code \& Standard Section Contents \\
\hline $\begin{array}{l}\text { NFPA } 801 . \\
2003\end{array}$ & Entire & & \\
\hline
\end{tabular}

Table 6-11 Fire Protection System Codes and Standards

\subsection{GANTRY CONTROL SYSTEM}

\subsubsection{Limit Switches}

\begin{tabular}{|l|l|l|l|}
\hline $\begin{array}{c}\text { Code \& } \\
\text { Standard }\end{array}$ & \multicolumn{1}{|c|}{ Section } & \multicolumn{1}{|c|}{ Title } & \multicolumn{1}{c}{ Code \& Standard Section Contents } \\
\hline ASME NOG.1 & 6000 & Entire & Electrical components \\
\hline ASME NOG.1 & 6440 & Limit Switches & $\begin{array}{l}\text { General, material, design and performance criteria and } \\
\text { component design. }\end{array}$ \\
\hline
\end{tabular}

Table 6-12 Limit Switch Codes and Standards 


\subsubsection{Gantry Lifting Speed Control System}

\begin{tabular}{|l|l|l|l|}
\hline $\begin{array}{c}\text { Code \& } \\
\text { Standard }\end{array}$ & Section & \multicolumn{1}{|c|}{ Title } & \multicolumn{1}{c|}{ Code \& Standard Section Contents } \\
\hline ASME NOG.1 & 6000 & Entire & Electrical components \\
\hline ASME NOG.1 & 6410 & Controllers & $\begin{array}{l}\text { Details design requirements applicable to speed controllers, } \\
\text { together with direction to other applicable standards }\end{array}$ \\
\hline ASME NOG.1 & 5331 & Hoist Speeds & Details recommended hoist speeds for rated loads \\
\hline
\end{tabular}

Table 6-13 Gantry Lifting Speed Control System Codes and Standards

\subsubsection{Lifting Control System}

\begin{tabular}{|l|l|l|l|}
\hline $\begin{array}{c}\text { Code \& } \\
\text { Standard }\end{array}$ & Section & \multicolumn{1}{|c|}{ Title } & \multicolumn{1}{c|}{ Code \& Standard Section Contents } \\
\hline ASME NOG.1 & 6000 & Entire & Electrical components \\
\hline ASME NOG.1 & 6432.3 & $\begin{array}{l}\text { Motor Power Circuit } \\
\text { Disconnecting Device }\end{array}$ & This section deals with controls to lock the crane on power loss \\
\hline CMAA 70 & $70-5.6 .11$ & $\begin{array}{l}\text { Protection and Safety } \\
\text { features }\end{array}$ & This section deals with controls to lock the crane on power loss \\
\hline
\end{tabular}

Table 6-14 Lifting Control System Codes and Standards

\subsubsection{Gantry Drive Speed Control System}

\begin{tabular}{|l|l|l|l|}
\hline $\begin{array}{c}\text { Code \& } \\
\text { Standard }\end{array}$ & Section & \multicolumn{1}{|c|}{ Title } & \multicolumn{1}{c|}{ Code \& Standard Section Contents } \\
\hline ASME NOG.1 & 6000 & Entire & Electrical components \\
\hline ASME NOG.1 & 6410 & Controllers & $\begin{array}{l}\text { Details design requirements applicable to speed controllers, } \\
\text { together with direction to other applicable standards }\end{array}$ \\
\hline ASME NOG.1 & 5331 & Hoist Speeds & Details recommended hoist speeds for rated loads \\
\hline
\end{tabular}

Table 6-15 Gantry Speed Control System Codes and Standards

\subsection{TRANSFER DOCK}

\subsubsection{Fixed Rail Stops}

\begin{tabular}{|c|l|l|l|}
\hline $\begin{array}{c}\text { Code \& } \\
\text { Standard }\end{array}$ & Section & \multicolumn{1}{|c|}{ Title } & \multicolumn{1}{c|}{ Code \& Standard Section Contents } \\
\hline ASME NOG.1 & 5458.5 & Trolley Stops & $\begin{array}{l}\text { Defines design criteria applicable to bumper design and energy } \\
\text { absorbing capacities. }\end{array}$ \\
\hline
\end{tabular}

\subsection{2}

Table 6-16 Fixed Rail Stop Codes and Standards

\subsubsection{Wheel blocks}

\begin{tabular}{|c|l|l|l|}
\hline $\begin{array}{c}\text { Code \& } \\
\text { Standard }\end{array}$ & Section & Title & \multicolumn{1}{c|}{ Code \& Standard Section Contents } \\
\hline ASME NOG.1 & 5452 & Wheels - Bridge and trolley & $\begin{array}{l}\text { This section deals with wheel type, material, loadings and } \\
\text { associated wheel components, for example shafts. }\end{array}$ \\
\hline
\end{tabular}

Table 6-17 Wheel Block Codes and Standards 


\section{REFERENCES}

\subsection{DOCUMENTS CITED}

BSC (Bechtel SAIC Company) 2004. Waste Package Transporter Preclosure Safety Analysis. $800-$ MQC-HET0-00200-000-00A. Las Vegas, Nevada: Bechtel SAIC Company.

BSC (Bechtel SAIC Company) 2005. Nuclear Safety Design Bases for License Application. 000-30RMGR0-00400-000-001. Las Vegas, Nevada: Bechtel SAIC Company

DOE (U.S. Department of Energy) 2004 Quality Assurance Requirements and Description. DOE/RW0333P, Rev. 15. Washington, D.C.: U.S. Department of Energy, Office of Civilian Radioactive Waste Management.

\subsection{CODES AND STANDARDS}

ASME NOG-1-2002. Rules for Construction of Overhead and Gantry Cranes Top Running Bridge, Multiple Girder. New York, New York: American Society of Mechanical Engineers.

CMAA 70-2000. Specifications for Top Running Bridge and Gantry Type Multiple Girder Electric Overhead Traveling Cranes. Charlotte, North Carolina: Crane Manufacturers Association of America.

NFPA 801. 2003. Standard for Fire Protection for Facilities Handling Radioactive Materials. 2003 Edition. Quincy, Massachusetts: National Fire Protection Association.

ANSI B5.48 - 1977. Ball Screws. New York, New York: American Society of Mechanical Engineers.

ASME B1.5 - 1997. Acme Screw Threads. New York, New York: American Society of Mechanical Engineers.

NFPA 801. 2003. Standard for Fire Protection for Facilities Handling Radioactive Materials. 2003. 


\section{REVIEWED MATERIAL}

The following lists indicate the project Documents, Drawings, Calculations/Analysis, Industry Codes and Standards, Regulatory Documents, Federal Regulations, and the DOE Documents reviewed in the performance of the study.

\subsection{REVIEWED DOCUMENTS}

Eleven Project documents were identified as the documents to be used for this study. These documents were identified as documents that had potential ITS standards that could be found by "pulling the string". Beginning with the Emplacement Gantry Design Calculation a list of documents with all references pertaining to the gantry was generated. From this list of reference documents, another sub list of references was generated. This process was continued until a list of all the documents that could potentially discuss ITS requirements had been generated.

For this review these eleven documents were scanned for ITS requirements:

Nuclear Safety Design Bases for License Application. - 000-30R-MGR0-00400-000-001.

Categorization of event sequences for License Application. - 000-00C-MGR0-00800-000-00Be

Project Design Criteria. -00-3DR-MGR0-00100-000-002

Project Requirements Document - TER-MGR-MD-000001

Preliminary Waste package Transport and Emplacement Equipment Design -

Project Functional and Operational Requirements. - TDR-MGR-ME-000003 rev 02

Emplacement and Retrieval System Description Document. - 800-3YD-HE00-00100-000-003d

Emplacement Gantry Design Calculation. - 800-MQC-HEE0-00200-000-00B

Bottom/Side Lift Gantry Conceptual Design. - ANL-WES-ME-000003 rev 01

Gantry Structural/Control System Analysis. - ANL-WER-MD-000001 rev 00

Shielding Design Calculations for Dry Facility \#1. - 800-00C-HEE0-00100-000-00Aa

Of the eleven documents reviewed there were only four documents found, that had any relevant requirements identified. The other seven documents were determined to be to old to have any additional applicable ITS requirements, or they referenced one of the four documents that had already been identified.

\subsection{REVIEWED DRAWINGS}

The following list is the available Project drawings depicting the design concept of the Emplacement Gantry

Emplacement and Retrieval General Arrangement Gantry. 800-M00-HEE0-00101-000-00B Emplacement and Retrieval General Arrangement Gantry Carrier. 800-MQ0-HES0-00101-000-00B

\subsection{REVIEWED CALCULATIONS/ANALYSIS}

The following Project Calculations and Analysis are the documents used in the development of the design concept of the Emplacement Gantry.

Emplacement Gantry Design Calculation. 800-MQC-HEE0-00200-000-00B

Gantry Structural/Control System Analysis. ANL-WER-MD-000001 rev 00

Bottom/Side lift Gantry Conceptual Design. ANL-WES-ME-000003 rev 01

Instrumentation and Controls for Waste Emplacement. ANL-WES-CS-000001 rev 00 


\subsection{REVIEWED SYSTEM DESCRIPTION DOCUMENTS}

The following is the current revision of the System Design Description Document pertaining to the Emplacement Gantry

Emplacement and Retrieval System Description Document. 800-3YD-HE00-00100-003

\subsection{REVIEWED INDUSTRY CODES AND STANDARDS}

The following represents the industry codes and standards, studied for applicability to the recognized ITS SSCs.

AISC 1997, - Seismic provisions for structural steel buildings ANSI N14.6-1993, - Special lifting devices for shipping containers of10000 lbs or more ANSI B5.48 - Ball Screws

ANSI B56.11.4 - Hook Type Forks and Fork Carriers for Powered Industrial Forklift Trucks. ANSI-ISA-S84.01 Application of safety Instrumented Systems for Process Industries part 1.pdf ANSI/ANS 57.1-1992, - Design requirements for light water reactor fuel handling systems ANSI/ANS-57:2-1983, - Design requirements for light water reactor spent fuel storage ANSU/ANS-57.7-1988, - Design criteria for independent spent fuel storage installations ANSUANS-57.9-1992, - Design criteria for independent spent fuel storage installations, dry type ANSI/AWS D14.1-97-1998, - Welding of industrial \& Mill cranes \& other Mechanical Handling equipment.

ASCE 4-98, - Seismic analysis of safety related nuclear structures \& commentary.

ASTM C992-89 (Re approved 1997), - Boron based neutron absorbing material

ASME B1.5 - 1997. Acme Screw Threads

ASME B30.1-2004 - Jacks

ASME B30.2-2001 - Overhead and Gantry cranes (top running single or multiple girder)

ASME B30.5a-2002, - Mobile and locomotive crane

ASME B30.9-2003, - Slings

ASME B30.10-1999, - Hooks

ASME B30.11-2004-1992 - Monorails and Underhung Cranes

ASME B30.16-2003, - Overhead hoists

ASME B30.20-2003, - Below the hook lifting devices

ASME B56. 11:4-1992 - Hook type forks and Fork carriers for powered industrial forklift trucks

ASME B56.1-2004 - Safety Standards for Low Lift and High Lift Trucks

ASME NOG-1-2002, - Rules for construction of overhead and gantry cranes

ASME NUM-1-2000 - Rules for the Construction of Cranes, Monorails and Hoists

AWS D1.1/D1.1M-2002, - Structural welding code

ASTM A759 - Standard Specification for Carbon Steel Crane Rails

AWS D1.6:1999, - Structural welding code - stainless steel.

CMAA-70-2000, - Specification for top running and gantry multiple girder cranes

CMAA-74-2000, - Specification for top running and under running single girder cranes.

Hanford Hoisting and Rigging Handbook

IEEE std 603-1998 - Standard Criteria for Safety Systems for Nuclear Power Generating Stations NFPA 801. 2003. Standard for Fire Protection for Facilities Handling Radioactive Materials. 2003

SAE J1078-01-April-1994 - (Reaffirmed APR94) - recommended method of analytically determining the competence of hydraulic telescopic cantilevered crane booms.

UL 508-December 2, 2003-Industrial Control Equipment

UL 583-July 12, 1999- Electric battery powered industrial trucks 
UL 698-March 15, 1999 - Industrial Control Equipment for use in Hazardous (Classified) Locations

\subsection{REVIEWED REGULATORY DOCUMENTS}

The following represents the regulatory documents, studied for applicability to the recognized ITS SSCs.

NUREG-0700 (O'Hara et al. 2002), - Human system interfaces.

NUREG-0554 (NRC 1979), - Single failure proof cranes for nuclear power plants

NUREG-0612 (NRC 1980), - Control of heavy loads at nuclear power plants

NUREG 1774 (July 2003) - A Survey of Cranes Operating Experience at U.S. Nuclear Power Plants

from 1968 through 2002

NUREG/CR-6407 (McConnell et al. 1996), - Classification of transport packaging \& dry spent fuel storage system components

Regulatory Guide 8.8 - radiation exposures

\subsection{REVIEWED FEDERAL REGULATIONS}

The following represents the Federal Regulations, studied for applicability to the recognized ITS SSCs.

10 CFR Part 20, - Standard for protection against radiation.

29 CFR Part 1910, - Occupational safety and health

10 CFR Part 71, - Packaging ant transportation of radioactive material

49 CFR Part 172, - Hazardous material table

49 CFR Part 173 - Shippers

\subsection{REVIEWED DOE DOCUMENTS}

The following represents the DOE Documents, studied for applicability to the recognized ITS SSCs.

DOE-STD-1090-2001, - Hoisting and rigging

DOE-HDBK-1140-2001 - Human Factors/Ergonomics Handbook 